\title{
Regulation of Growth and Carbohydrate Metabolism in Rice (Oryza Sativa L.) seedlings by Selenium and Sulphate
}

\author{
Debarati Das ${ }^{1}$, Prabal Das ${ }^{1} \&$ Asok K. Biswas ${ }^{1}$ \\ ${ }^{1}$ Plant Physiology and Biochemistry Laboratory, Centre for Advanced study, Department of Botany, University \\ of Calcutta, 35, Ballygunge Circular Road, Kolkata-700019, West Bengal, India
}

Correspondence: Asok K. Biswas, Department of Botany, University of Calcutta, 35, Ballygunge Circular Road, Kolkata-700019,West Bengal, India. Tel: 033-2425-8816. E-mail: asokkbiswas@yahoo.com

Received: January 8, 2018

Accepted: January 26, 2018 Online Published: February 25, 2018

doi:10.5539/jps.v7n1p61

URL: https://doi.org/10.5539/jps.v7n1p61

\begin{abstract}
Selenium is an essential and also toxic trace element for organisms including plants. We studied the role of selenium $\left(\mathrm{Na}_{2} \mathrm{SeO}_{4}\right)$ on growth and carbohydrate metabolism and its interaction with sulphate $\left(\mathrm{Na}_{2} \mathrm{SO}_{4}\right)$ in rice (Oryza sativa L. cv. Satabdi) seedlings. Low concentration of selenium $(2 \mu \mathrm{M})$ showed stimulatory effect on growth as opposed to its higher concentration $(50 \mu \mathrm{M})$. Selenium was found to accumulate in a dose dependent linear pattern in the plant tissues. Exposure to selenate increased both reducing and non reducing sugar contents in the rice seedlings accompanied with an increase in the activities of sugar metabolizing enzymes like Sucrose Synthase (EC 2.4.1.13) and Sucrose Phosphate Synthase (EC 2.4.1.14). An increase in Starch Phosphorylase (EC 2.4.1.1) activity corresponded with the reduction in starch contents in the rice seedlings. Since Selenium is chemically analogous to sulphate, simultaneous application of sodium sulphate $(10 \mathrm{mM})$ and selenate $\left(\mathrm{Na}_{2} \mathrm{SeO}_{4}\right)$ was found to ameliorate partially or totally all the tested parameters under selenate treatment alone resulting in alteration of growth and development of the test seedlings.
\end{abstract}

Keywords: Amelioration, growth, rice, selenium, sugar metabolism, sulphate

Abbreviations: $\beta$-ME - beta mercaptoethanol, cv.- cultivar, DNSA- 3,5-dinitrosalicylic acid, dw - dry weight, DTT- dithiothreitol, EDTA- ethylenediamine tetraacetic acid, fw- fresh weight, HEPESN-2-Hydroxyethylpiperazine-N'-2-ethanesulfonic acid, KI- potassium iodide, PFD- photon flux density, PMSFphenyl methyl sulphonylfluoride, S- Sodium sulphate salt, Se- Sodium selenate salt, SE- standard error, SPSsucrose phosphate synthase, SS- sucrose synthase, TCA- trichloroacetic acid ,UDP- uridine-di-phosphate.

\section{Introduction}

The present investigation was undertaken to widely examine the influence of selenium singly as well as in combination with sulphate on the metabolic status of sugar, starch and different sugar metabolizing enzymes in germinating rice (Oryza sativa L. cv. Satabdi) seedlings.

\subsection{Literature Review}

Selenium, a chalcogen of sulphur, is a Group VI A, Period 4 trace element of oxygen sulphur family according to the periodic table (Bodnar, Konieczka \& Namiesnik, 2012). It has a significant role to play in the metabolism of both animals and plants. Selenium alters oxidative stress, DNA methylation, DNA repair, apoptosis, cell proliferation, carcinogen metabolism, hormone production and immune function in different animal systems (Dinkova-Kostova 2013; Hatfield, Tsuji, Carlson \& Gladyshev, 2014). In plants, selenium does a paradigm shift between playing the role of an antioxidant or a pro-oxidant at specific concentration (Pennanen, Xue \& Hartikainen 2002). Present interest in selenium is focused on health benefits using biofortified plants with high selenium contents as a source of cancer preventive selenium compounds (Zhao \& McGrath 2009; Dinkova-Kostova 2013).

In plants, selenium at low concentration enhances growth and ability to withstand stress (Hartikainen et al., 2000; Sun et al., 2010) whereas it becomes toxic at higher concentrations (Mroczek-Zdyrska \& Wójcik 2012). In electrochemical series, selenium being physico-chemically similar to sulphur acts as a chalcogen (Bodnar et al., 2012). According to Missana et al. (2009) and Winkle et al. (2015), among the two inorganic forms of selenium, selenate $\left(\mathrm{SeO}_{4}{ }^{2-}\right)$ is more bioavailable than selenite $\left(\mathrm{SeO}_{3}{ }^{2-}\right)$ from anthropogenic sources. In plants, selenate 
$\left(\mathrm{SeO}_{4}{ }^{2-}\right)$ is actively transported through sulfate transporters as it shows chemical similartity with sulfate ion (Dumont et al., 2006, El Kassis et al., 2007; Gigolashvili \& Kopriva, 2014).Therefore, the presence of sulfate ion can influence uptake of selenium in plant tissue as observed in Astragalus, Aradidopsis, Brassica and Stanley species by Sors et al. (2005), El Kassis et al. (2007), Cappa et al. (2014) and Schiavon et al. (2015) respectively.

In growing plant tissues, accumulation of sugar occurs to counteract stressful environment through osmotic alterations (Mishra \& Dubey 2008; Rosa et al., 2009). The primary end products of photosynthesis sucrose is one of the major form of translocated carbon (Zhou et al., 2002) whereas starch comprises the temporary reserve form of carbon which gets finally stored in the grains (Zeeman et al., 2004). The enzyme Sucrose Phosphate Synthase catalyses sucrose synthesis in the plant tissues whereas Sucrose Synthase, present in cytosol, helps in sucrose breakdown in vivo and translocating the assimilates to diverse pathways in plant storage cells (Huber \& Huber, 1996). Yang et al. (2001) reported that in plants, Starch Phosphorylase hydrolyzes starch by incorporating phosphate at the non-reducing end.

\section{Material and Methods}

\subsection{Plant Materials and Selenium Treatments}

Rice (Oryza sativa L. cv. Satabdi ) seeds were obtained from the State Rice Research Institute, Chinsurah, Hooghly, West Bengal, India. The seeds were surface sterilized with sodium hypochlorite $(0.5 \%)$ for 15 mins. and then washed thoroughly in distilled water. A batch of 100 seeds were arranged in petri dishes with filter papers containing $20 \mathrm{~mL}$ sterile water (as control). Different concentrations of sodium selenate $\left(\mathrm{Na}_{2} \mathrm{SeO}_{4}\right)$ purchased from Loba-Chemie, India or selenate in combination with sodium sulphate $\left(\mathrm{Na}_{2} \mathrm{SO}_{4}\right)$ purchased from Merck, India were applied to the experimental sets. The selenate concentrations used in the present experiment were similar to selenate concentrations found in different field conditions.

For 48 hours seeds were placed in a germinator $\left(30 \pm 2^{\circ} \mathrm{C}\right)$ followed by exposure to 16 hours photoperiod and $75 \%$ relative humidity. The rice seedlings were further grown in modified Hoagland solution prepared with respective selenate and sulphate concentrations which were replaced on every alternate day for twenty-one days. After twenty-one days treatment plants were collected, washed properly, root and shoot were separated and either used as fresh material or stored in $-80^{\circ} \mathrm{C}$ for the following experiments. All the experiments were conducted in a randomized design and repeated thrice.

\subsection{Morphological Studies}

Following twenty one days of treatment, the effects of selenate singly and with sulphate were observed on test seedlings. Length of root and shoot of rice seedlings as morphological data were recorded and the root tolerance index (RTI) and shoot tolerance index (STI) were calculated from the root and shoot length data respectively.

\subsection{Extraction and Estimation of Selenium Content}

Total selenium contents were measured from acid digested $1 \mathrm{~g}$ dried root and shoot samples of rice. The dried samples were digested in a Microwave Digestor using $7 \mathrm{ml}$ of $\mathrm{HNO} 3(65 \%), 5 \mathrm{ml} \mathrm{HCl}$ and $2 \mathrm{ml} \mathrm{of} \mathrm{H}_{2} \mathrm{O}_{2}$ for about $60 \mathrm{~min}$. After digestion, Selenium contents were measured by inductively coupled plasma optical emission spectroscopy (ICP-OES) iCPA 6000 series (Thermo Scientific) using a standard curve prepared from known concentrations of selenium solutions and expressed as $\mathrm{m} \mathrm{kg}^{-1} \mathrm{dw}$.

\subsection{Estimation of Starch and Sugar Content}

Total soluble sugar was assayed according to Dubois et al. (1956). $1 \mathrm{~g}$ root and shoot samples were crushed with $80 \%$ ethanol and centrifugation was done for 20 minutes at $2000 \mathrm{rpm}$. 5\% phenol $(0.05 \mathrm{ml})$ and sulphuric acid (98\%) were mixed with $1 \mathrm{ml}$ supernatant followed by $20 \mathrm{~min}$ incubation in water bath at $30^{\circ} \mathrm{C}$. Finally, OD values of the yellow orange colour solution were taken in Hitachi-2000 spectrophotometer at $490 \mathrm{~nm}$. Standard curve of glucose was prepared using known concentrations of glucose (Nelson 1944) and total soluble sugar contents was calculated accordingly. Total soluble sugar was expressed in terms of $\mathrm{mg} \mathrm{g}^{-1} \mathrm{fw}$.

Reducing sugar was quantified according to the method of Miller (1972). $1 \mathrm{~g}$ plant samples were homogenized in $80 \%$ ethanol followed by 20 minutes centrifugation at $2000 \mathrm{rpm}$. To $1 \mathrm{ml}$ of alcoholic supernatant, DNSA was mixed and boiled for 5 minutes. OD was taken at $515 \mathrm{~nm}$ in Hitachi-2000 spectrophotometer. Glucose concentration was quantified using a standard curve of glucose and the amount of reducing sugar was expressed as $\mathrm{mg} \mathrm{g}^{-1} \mathrm{fw}$. Amount of non-reducing sugar was calculated by substracting the value of reducing sugar from the value of total sugar.

Quantification of starch was carried out according to the method of McCready et al.(1950).The remaining mass, gained after centrifugation for the extraction of total soluble sugar was again suspended in distilled $\mathrm{H}_{2} \mathrm{O}$ and 
perchloric acid was added followed by centrifugation at $2000 \mathrm{rpm}$ for 20 minutes. The supernatant was then collected, poured in conical flasks and the final volume was made upto $100 \mathrm{ml}$ by addition of distilled water. Starch content was measured from $1.0 \mathrm{ml}$ of filtrate following the same protocol of total soluble sugar. Starch content was quantified in terms of glucose and factor 0.9 was applied for the conversion of glucose to starch. Amount of starch was expressed in terms of $\mathrm{mg} \mathrm{g}^{-1} \mathrm{fw}$.

\subsection{Preparation of Extracts and Enzyme Assays}

Starch phosphorylase activity was determined according to Dubey and Singh (1999). Crushing was done in 50 $\mathrm{mM}$ citrate buffer (pH 6.0) containing $\beta$-ME $(5 \mathrm{mM})$, EDTA $(1 \mathrm{mM})$, PMSF $(1 \mathrm{mM})$ and centrifugation was carried out for $20 \mathrm{~min}$ at $10000 \mathrm{rpm}$ at $40^{\circ} \mathrm{C}$. The assay mixture constituted of $50 \mathrm{mM}$ citrate buffer $(\mathrm{pH} 6.0)$, $0.1 \mathrm{mM}$ glucose-1-phosphate, $5 \%$ soluble starch $(\mathrm{w} / \mathrm{v})$, and enzyme extract to make the final volume upto $4.0 \mathrm{ml}$. 5\% TCA was added after 10 minutes to terminate the reaction. Phosphorous contents were measured after centrifugation according to the method of Fiske and Subbarow (1925). Enzymatic activity was expressed as $\mu \mathrm{mol}$ of Pi liberated $\mathrm{g}^{-1}$ protein $\min ^{-1}$.

For the assay of Sucrose Phosphate Synthase (SPS) and Sucrose Synthase (SS), the plant tissues were homogenized following the method of Hubbard et al. (1989) and assayed according to Miron and Schaffer (1991). Plant samples were crushed in $50 \mathrm{mM}$ HEPES-NaOH buffer ( $\mathrm{pH} 7.5)$ containing EDTA (1 mM), $\mathrm{MgCl}_{2}$ $(5 \mathrm{mM}), 0.05 \%$ (v/v) Triton X-100 and DTT $(2.5 \mathrm{mM})$ followed by centrifugation at $10000 \mathrm{rpm}$ for $10 \mathrm{~min}$. Assay mixture for SPS constitute of enzyme extract, $50 \mathrm{mM}$ HEPES-NaOH buffer (pH 7.5), fructose-6-phosphate $(25 \mathrm{mM})$, glucose-6-phosphate (25 mM), $\mathrm{MgCl}_{2}(15 \mathrm{mM})$, UDP-glucose $(25 \mathrm{mM})$.The reaction was stopped after $30 \mathrm{~min}$ incubation at $37^{\circ} \mathrm{C}$ by addition of $30 \% \mathrm{KOH}$. Reaction mixture of sucrose synthase assay was like sucrose phosphate synthase except that it required fructose $(25 \mathrm{mM})$ instead of fructose-6-phosphate and glucose-6-phosphate was absent. Sucrose hydrolysed or formed by SS or SPS catalysed reaction was measured according to Vassey et al. (1991). The enzyme activities were expressed as nmol sucrose hydrolysed or formed $\mathrm{g}^{-1}$ protein $\mathrm{min}^{-1}$ respectively.

\subsection{Protein Estimation}

For all enzyme preparations the concentrations of protein were measured according to Lowry et al. (1951) using bovine serum albumin (BSA) as standard.

\subsection{Statistical Analysis}

The experiments were carried out in a completely randomized design (CRD) with three repeats, each treatment comprising a single petridish containing 100 seeds. The data and significant differences among the mean values were compared by descriptive statistics $( \pm \mathrm{SE})$ followed by Student's' $t$ '-test. The alphabet 'a' indicates high statistical significance at $\mathrm{P} \leq 0.05$ as compared to water control.

\section{Results}

\subsection{Influence on Seedling Growth}

Exposure of rice seedlings to different concentrations of selenate showed both stimulatory and inhibitory effects on elongation of root and shoot lengths. Maximum stimulation occurred in $2 \mu \mathrm{M}$ selenate treated rice seedlings which were about $36 \%$ in root and about $31 \%$ in shoot over water control.Thereafter, a sharp decline were observed in growth of rice seedlings which were about $34 \%$ and $67 \%$ in root and about $15 \%$ and $51 \%$ in shoot under $20 \mu \mathrm{M}$ and $50 \mu \mathrm{M}$ selenate treatment respectively (Figure 1). The root and shoot tolerance index also concomitantly reduced with increase in concentrations of selenate. Roots were found to be more affected than shoot in the test cultivar.

Joint application of sulphate $(10 \mathrm{mM})$ along with selenate altered the effect caused by selenate alone and induced stimulation in both root and shoot length. The root and shoot length almost doubled under combined application of $2 \mu \mathrm{M}$ selenate and sulphate whereas the inhibitory effect on growth were narrowed down to a maximum of about $33 \%$ in root and by about $28 \%$ in shoot over water control. Similarly, joint application of said concentrations of selenate with $10 \mathrm{mM}$ sulphate increased the RTI and STI respectively in the test cultivar (Figure 2). 


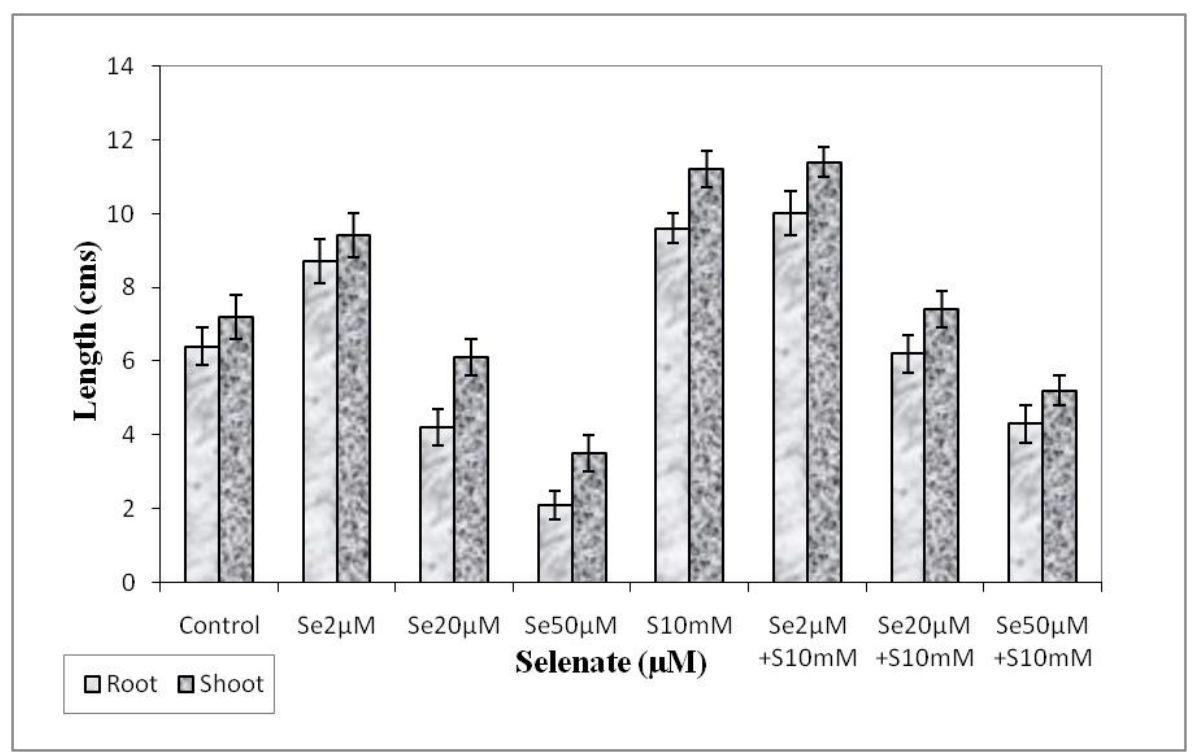

Figure1. Effect of selenate and/or sulfate on shoot and root lengths in rice (cv. Satabdi) seedlings. The data were recorded from 21 days old seedlings. Each bar is the mean \pm SE with three repeats

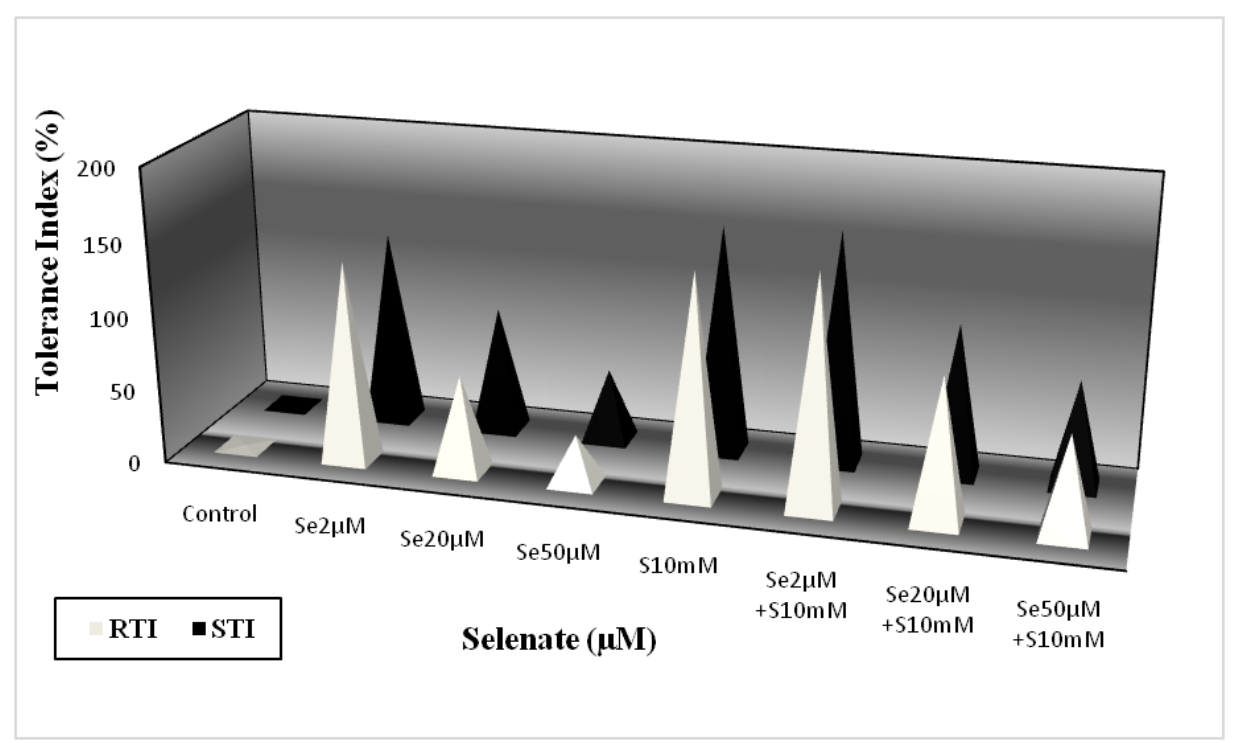

Figure2. Effect of selenate and/or sulfate on RTI and STI in rice (cv. Satabdi) seedlings. The data were recorded from 21 days old seedlings. Each bar is the mean $\pm \mathrm{SE}$ with three repeats

\subsection{Influence on Selenium Contents}

The selenium contents were negligible in root and shoot of rice seedlings grown only in water (control) but it increased markedly with the increasing amount of selenium added to the test solutions (Figure 3). In roots, maximum accumulation of Se took place under $50 \mu \mathrm{M}$ selenate treatment that was about 5 times more than that found in shoots at the same concentration of selenium. Joint application of selenate and sulphate $(10 \mathrm{mM})$ showed varied responses on selenium uptake. In root, the selenium contents increased under $2 \mu \mathrm{M}$ selenium and $10 \mathrm{mM}$ sulphate treatment whereas it decreased in $50 \mu \mathrm{M}$ selenium plus sulphate treated test samples compared to the level under same concentration of selenate alone. In shoot, $10 \mathrm{mM}$ sulphate applied jointly with $2 \mu \mathrm{M}, 20$ $\mu \mathrm{M}$ and $50 \mu \mathrm{M}$ selenium showed a decline in selenium uptake over water control. 


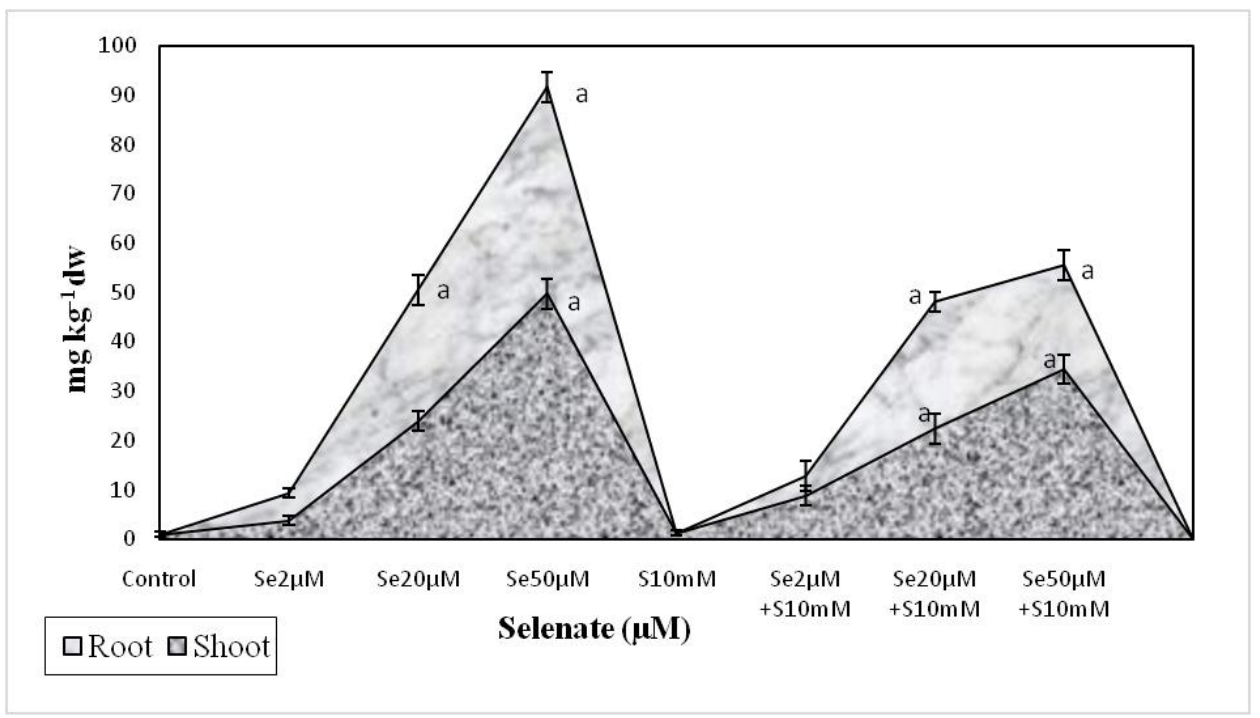

Figure 3. Effect of selenate and/or sulfate on selenium content in rice (cv. Satabdi) seedlings. The data were recorded from 21 days old seedlings. Each bar is the mean $\pm \mathrm{SE}$ with three repeats. The alphabet ' $a$ ' indicates high statistical significance at $\mathrm{P} \leq 0.05$ as compared to water control

\subsection{Influence on Starch Contents}

In both root and shoot of the test seedlings, the starch contents decreased with increasing selenate treatment although it was higher with respect to water control. The starch level registered a decline on an average of about $18 \%$ in roots and about $8 \%$ in shoots of the treated rice seedlings (Figure 4).Joint application of selenate with $10 \mathrm{mM}$ sulphate altered the effect caused by selenate alone in the test cultivar. Co-application of $10 \mathrm{mM}$ sulphate along with $20 \mu \mathrm{M}$ and $50 \mu \mathrm{M}$ selenate increased starch contents on an average by about $14 \%$ in roots and by about $10 \%$ in shoot of rice seedlings respectively over water control (Figure 4).

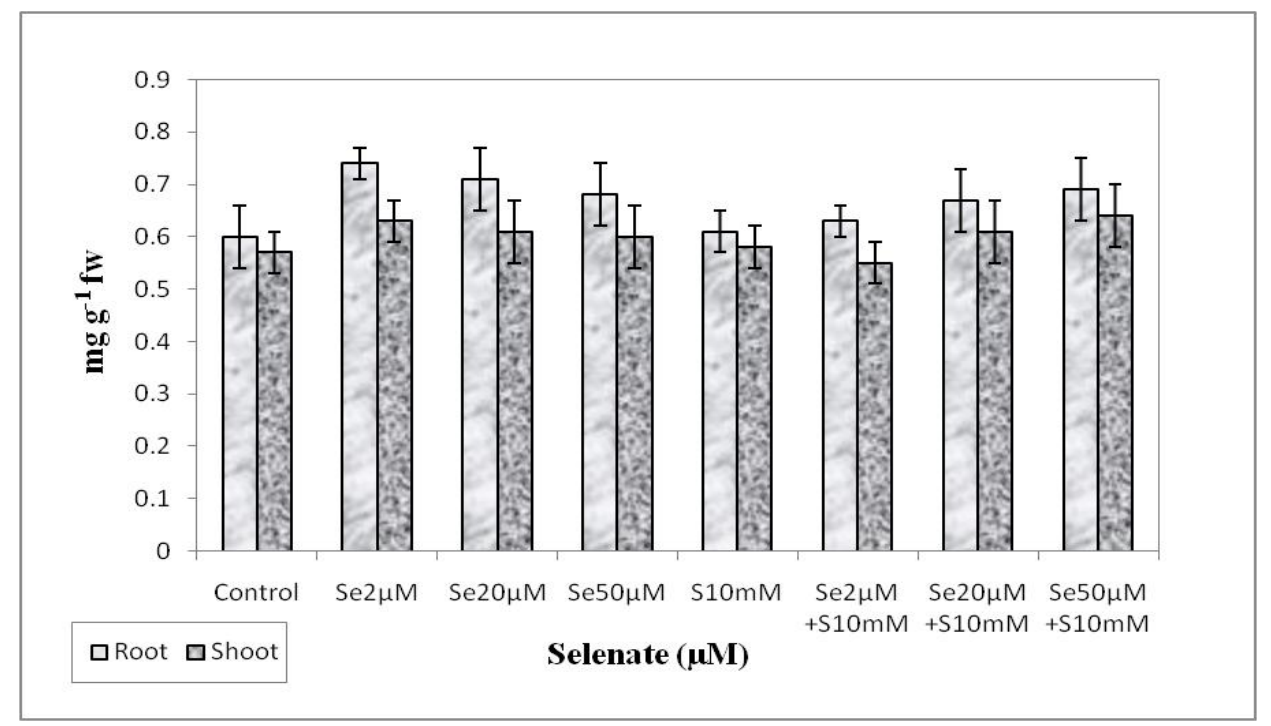

Figure 4. Effect of selenate and/or sulfate on starch contents in rice (cv. Satabdi) seedlings. The data were recorded from 21 days old seedlings. Each data point is the mean $\pm \mathrm{SE}$ with three repeats

\subsection{Influence on Reducing Sugar Contents}

The reducing sugar contents increased in both roots and shoots of the test cultivar with increase in selenate treatment. The reducing sugar contents were stimulated by about $14 \%, 23 \%$ and $28 \%$ in roots and by about $6 \%, 22 \%$ and $35 \%$ in shoots of rice seedlings under $2 \mu \mathrm{M}, 20 \mu \mathrm{M}$ and $50 \mu \mathrm{M}$ selenate treatment respectively over 
water control (Figure 5). Maximum inhibition were recorded in rice seedlings treated with $50 \mu \mathrm{M}$ selenate and sulphate $(10 \mathrm{mM})$ where the reducing sugar level decreased by about $11 \%$ in roots and about $21 \%$ in shoots of rice seedlings with respect to water control (Figure 5).

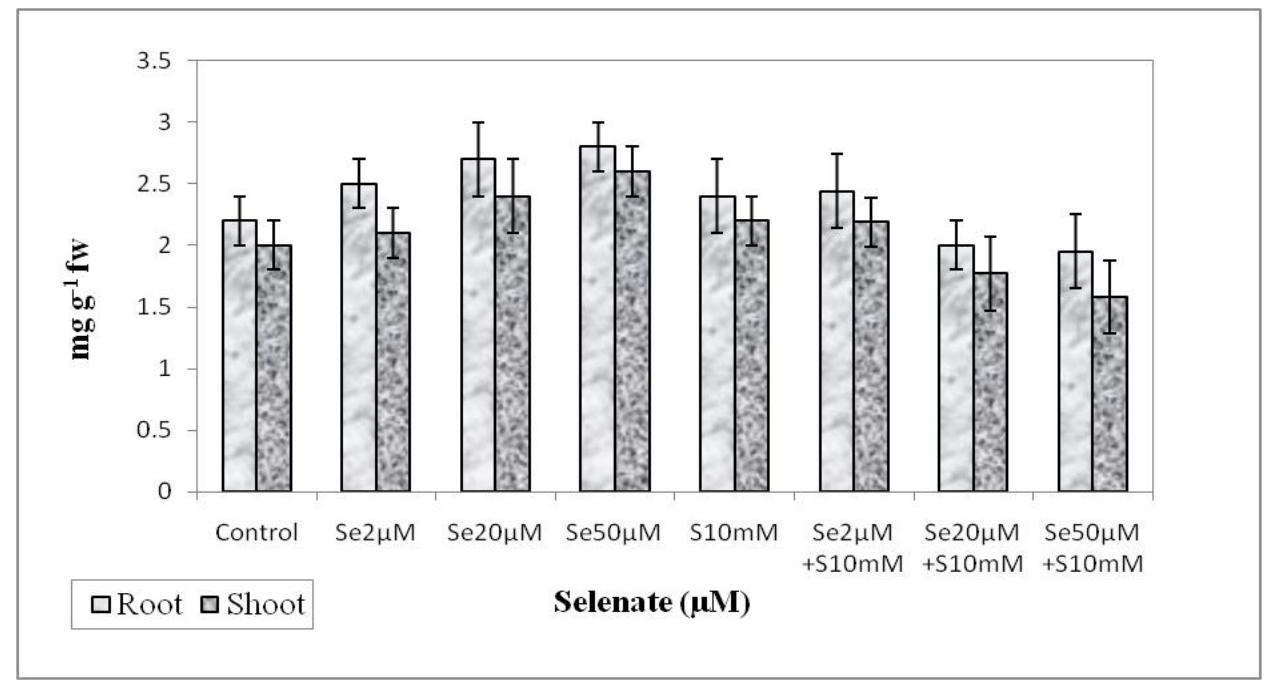

Figure 5. Effect of selenate and/or sulfate on reducing sugar contents in shoots of rice ( cv. Satabdi) seedlings.

The data were recorded from 21 days old seedlings. Each data point is the mean \pm SE with three repeats

\subsection{Influence on Non-Reducing Sugar Content}

The level of non reducing sugar were enhanced by about $11 \%, 23 \%$ and $28 \%$ in roots and $13 \%, 19 \%$ and $32 \%$ in shoots of $2 \mu \mathrm{M}, 20 \mu \mathrm{M}$ and $50 \mu \mathrm{M}$ selenate treated rice seedlings respectively over water control (Figure 6).Application of said concentrations of selenate in combination with sulphate $(10 \mathrm{mM})$ decreased the level of non reducing sugar contents by about $3 \%, 17 \%$ and $21 \%$ in roots and by about $4 \%, 10 \%$ and $15 \%$ in shoots of test seedlings respectively over water control (Figure 6).

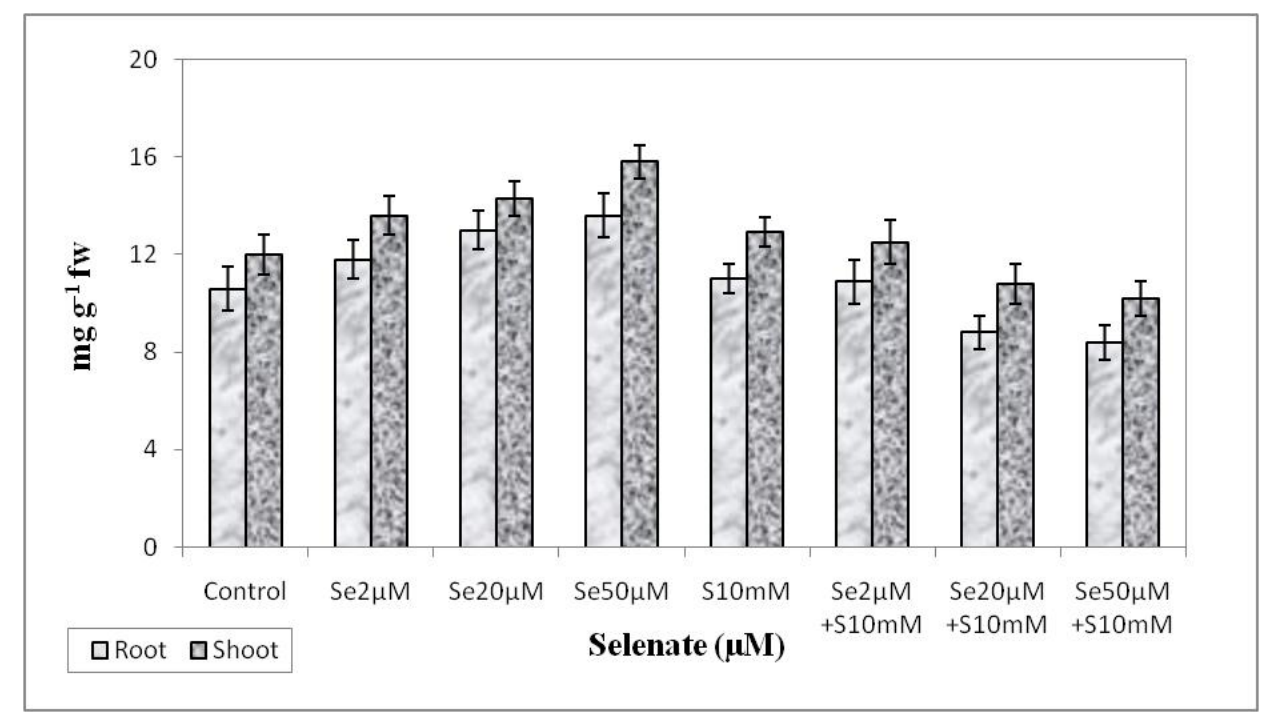

Figure 6. Effect of selenate and/or sulfate on non reducing sugar contents in shoots of rice ( cv. Satabdi) seedlings. The data were recorded from 21 days old seedlings. Each data point is the mean $\pm \mathrm{SE}$ with three repeats

\subsection{Influence on Sucrose Synthase Activity}

The activity of sucrose synthase (SS) was increased in both roots and shoots of selenate treated rice seedlings. The enzyme activity increased on an average by about $22 \%$ in roots and $21 \%$ in shoots of the test samples compared to water control (Figure 7). Application of higher concentrations of selenate with $10 \mathrm{mM}$ sulphate 
simultaneously, reduced the enzyme activity to a maximum of about $12 \%$ in roots and about $16 \%$ in shoots of the test cultivar with respect to selenate treatment alone.

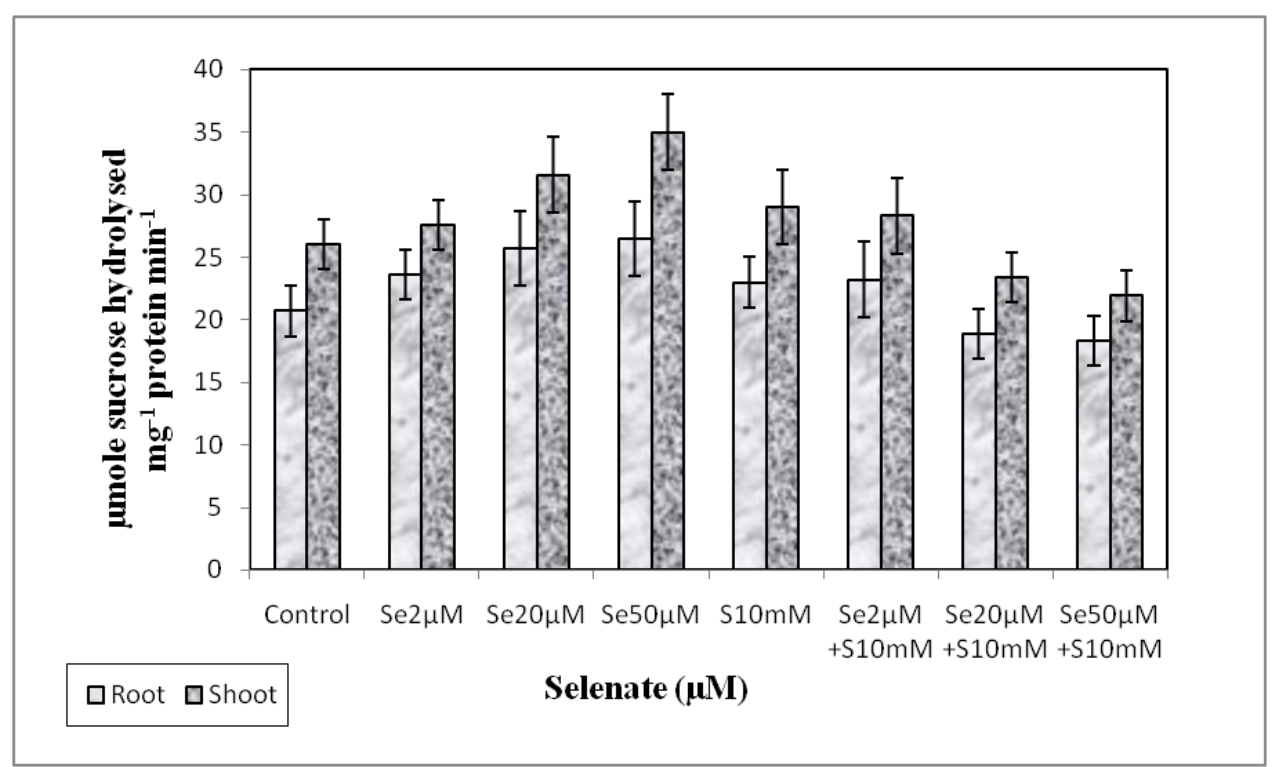

Figure 7. Effect of selenate and/or sulfate on sucrose synthase activity in rice (cv. Satabdi) seedlings. The data were recorded from 21 days old seedlings. Each data point is the mean \pm SE with three repeats

\subsection{Influence on Sucrose Phosphate Synthase Activity}

The sucrose phosphate synthase activity was stimulated in both root and shoot of test cultivar under selenate treatment (Figure 8). The enzyme activity recorded a linear increment of about $12 \%, 27 \%$ and $32 \%$ in roots and about $15 \%, 21 \%$ and $33 \%$ in shoots of $2 \mu \mathrm{M}, 20 \mu \mathrm{M}$ and $50 \mu \mathrm{M}$ selenate treated rice seedlings respectively. Joint application of selenate with $10 \mathrm{mM}$ sulphate reversed the effect caused by selenate alone and reduced the enzyme activity on an average by about $12 \%$ in roots and by about $15 \%$ in shoots of the test samples with respect to water control.

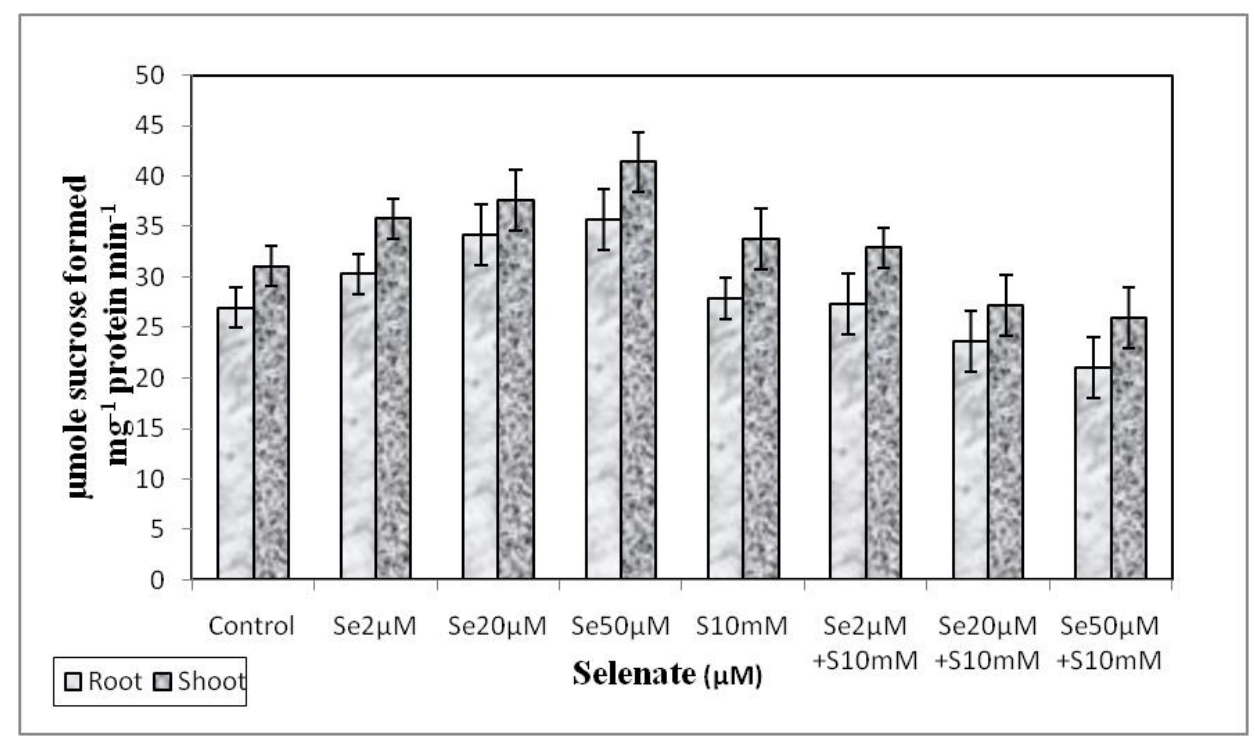

Figure 8. Effect of selenate and/or sulfate on sucrose phosphate synthase activity in rice (cv. Satabdi) seedlings.

The data were recorded from 21 days old seedlings. Each data point is the mean \pm SE with three repeats

\subsection{Influence on Starch Phosphorylase Activity}

Rice seedlings showed both stimulatory and inhibitory effects on starch phosphorylase (SP) activity due to 
selenate treatment .The effect was less pronounced in shoot than root of test seedlings. Initially the enzyme activity declined by about $10 \%$, on an average, both in root and shoot of test seedlings under $2 \mu \mathrm{M}$ selenate treatment. Thereafter, the enzyme activity increased considerably to a maximum of about $32 \%$ in root tissue and $21 \%$ in shoot tissue of rice seedlings under $50 \mu \mathrm{M}$ selenate treatment compared to water control (Figure 9).Coapplication of $2 \mu \mathrm{M}$ selenate and sulphate inhibited the promotive effect on the enzyme activity by about $6 \%$, on an average, in root and shoot of the test cultivar. The enzyme activity decreased by about $25 \%$ in root and about $8 \%$ in shoot, on an average, under combined application of higher concentrations of selenate with $10 \mathrm{mM}$ sulphate.

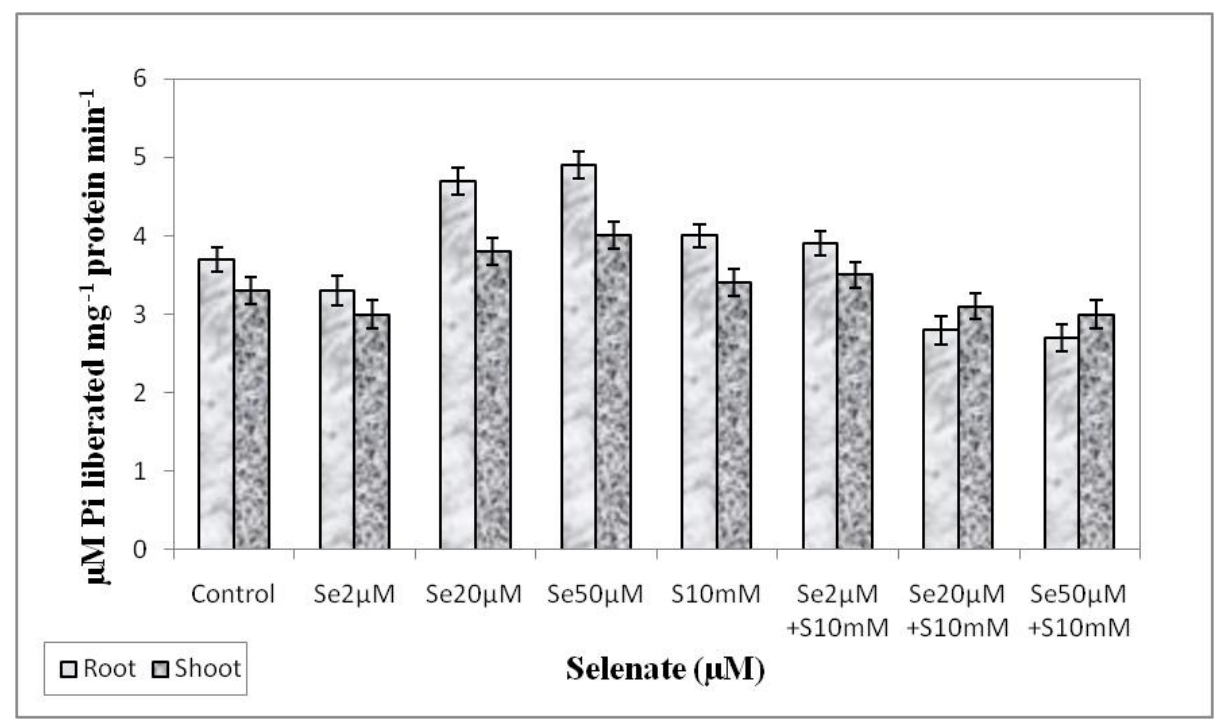

Figure 9. Effect of selenate and/or sulfate on starch phosphorylase activity in rice (cv. Satabdi) seedlings. The data were recorded from 21 days old seedlings. Each data point is the mean \pm SE with three repeats

\section{Discussion}

\subsection{Influence of Selenate and Sulphate on Selenate Uptake and Growth of Seedlings}

Selenium (Se) exposure showed variable influence and altered normal growth and development in the seedlings of rice cultivar (cv.Satabdi) under selenate treatment. Low concentration of selenate $(2 \mu \mathrm{M})$ showed stimulatory effect on growth in comparison to higher concentrations of selenium $(\geq 20 \mu \mathrm{M})$ which inhibited the development of the rice seedlings. Roots were most affected than shoots and were found to be severely injured with browning at the apical tissue region. Similar observations were noted by Khattab et al. (2004) and Chu et al. (2013) on other plant species. The level of selenium increased linearly in a dose-dependent manner with increasing concentrations of selenate in the test seedlings whereas joint application of selenium and sulphate at concentrations higher than $2 \mu \mathrm{M}$ selenate, reduced the intake of selenium but induced a dose-dependent increase in sulphate accumulation in the plant tissue. Similar increase in sulphate accumulation on selenium supplementation was reported in shoots of many plants including Brassica oleracea (Kopsell et al., 2000). Our results are also supported by White et al. (2004) who observed similar alterations occuring in Arabidopsis thaliana.

\subsection{Effect of Selenate and Sulphate on Carbohydrate Metabolism}

The flow of photosynthetic assimilates from source to sink organ helps to regulate partitioning of dry matter in plants which is important during plant growth and development. It is also considered as a limiting factor in crop yield. Atmospheric carbon is photosynthetically fixed in the form of sucrose and starch at the end of photosynthesis. Starch acts as a temporary storage form of fixed carbon in the chloroplast and is finally stored in the cereal grains. Sucrose is the primary transportable sugar in plant system. Presence of enhanced quantities of soluble reducing and non-reducing sugars in the test seedlings coincide with the activity of Sucrose Synthase and Sucrose Phosphate Synthase. Such enhancement in sugar contents might help to increase cellular respiration in order to counteract the toxic effects of high selenium concentrations in the root and shoot of the test seedlings. Previously, it had been demonstrated by Quick et al. (1989), Dubey and Singh (1999) and Devi et al. (2007) that water, salinity and cadmium stress led to increment in soluble sugar contents. According to Couee et al. (2006) 
abiotic stresses also seems to provoke accumulation of soluble sugars as a counteractive way to ensure the maintainance of homeostasis in the cells. The present study also showed a decrease in starch contents under high selenate concentrations which may occur due to starch degradation, or reduced synthesis of starch in order to counteract selenium stress. Similar results were documented by Rahoui et al. (2008) in cadmium treated Vicia faba seedlings. Starch phosphorylase catalyses starch hydrolysis by incorporating phosphate (Salisbury \& Ross, 1991). Increment of starch hydrolysing enzyme, starch phosphorylase activity is correlated with the decrease in starch contents as observed in the test seedlings. Sucrose Synthase (SS) has a vital role in sucrose metabolism in plants. Sucrose synthase is a cytosolic enzyme that regulates synthesis and breakdown of sucrose in plants (Zheng et al. 2011). Sucrose phosphate Synthase (SPS) regulates carbon flux in a reversible reaction forming sucrose-6-phosphate from UDP-glucose and fructose-6-phosphate during sucrose formation in higher plants. In the study an increase in Sucrose Synthase and Sucrose Phosphate Synthase activities were recorded both in root and shoot of rice seedlings treated with high concentrations of selenium. Similar increase in activity of Sucrose Synthase was observed by Verma \& Dubey (2001) in rice seedlings under cadmium toxicity. According to Yang et al. (2001) enhanced activity of said enzymes related to sucrose metabolism may have positive effect in adaptation of the rice seedlings under selenium stressed condition by osmotic adjustment, thus shielding the biomolecules and membranes from dehydration. When the test seedlings were further treated jointly with high concentrations of selenate $(>2 \mu \mathrm{M})$ and sulphate $(10 \mathrm{mM})$, the activity of the enzymes were found to be partially or completely altered.

Majority of mankind on earth consumes rice (Oryza sativa L.).Rice is also considered as the most important staple food crop in India. Rice is the second most efficient selenium accumulator plant among the cereal crops and thus possesses the capability to become an important source of dietary selenium (Poblaciones et al. 2014). In order to produce food products biofortified with selenium, it becomes necessary to choose sustainable crop varieties that accumulates Se at a moderate concentration in their edible parts as discussed by Mayer et al.(2008), Liu et al. (2011),Yin and Yuan (2012) and Wu et al. (2015). Selenate is analogous to sulphate. Therefore, external application of sulphate along with selenate to rice seedlings may help to overcome the detrimental effects caused by high concentrations of selenium which is evident from our investigations. The test results also indicate that the role of selenium and sulphate are complex in the rice growth system. Therefore, in order to produce Se-enriched rice, it is important to comprehend the interactions that occurs between selenium and sulphate in the plant system at all levels. Otherwise, it may result in the entry of excessive selenium into the food chain, consequently injuring human health.

\section{Conclusion}

The present study on role of selenium on carbohydrate metabolism in rice (Oryza sativa 1.) cv. Satabdi seedlings and its interaction with sulphate is of significance as it is one of the few reports on selenium sulphur interaction in rice plants available to the best of our knowledge. Since supplementation of rice seedlings with sodium selenate increased selenium contents in the test cultivar and its toxic level was regulated on addition of sodium sulphate, this might provide an efficient and effective way to supervise selenium concentrations during biofortification in cereal plants. Our investigation is the first step towards understanding the physiological and biochemical interactions involved in the regulation of selenium intake by sulphate in rice seedlings and more research on selenate sulphate relationship is required to develop a selenium biofortified cereal crop which may serve as a sustainable and economic dietary source of selenium in the environment.

\section{Acknowledgements}

The authors are grateful to University Grants Commission for financial assistance and Centre of Advance Study, Department of Botany, University of Calcutta for providing infrastructural facilities and instruments.

\section{References}

Bodnar, M., Konieczka, P., \& Namiesnik, J. (2012).The properties, functions, and use of selenium compounds in living organisms. Journal of Environmental Science and Health Part C., 30, 225-252. https://doi.org/10.1080/10590501.2012.705164.

Cappa, J. J., Cappa, P. J., El Mehdawi, A. F., McAleer, J. M., Simmons, M. P., \& Pilon-Smits, E. A. (2014) Characterization of selenium and sulfur accumulation across the genus Stanleya (Brassicaceae): a field survey and common-garden experiment. American Journal of Botany, 101, 830-839. https://doi.org/10.3732/ajb.1400041.

Chu, J. Z., Yao, X. Q., \& Zhang, Z. N. (2010). Responses of wheat seedlings to exogenous selenium supply under cold stress. Biological Trace Element Research, 136(3), 355-363. 
https://doi.org/10.1007/s12011-009-8542-3

Couée, I., Sulmon, C., Gouesbet, G., \& El Amrani, A. (2006). Involvement of soluble sugars in reactive oxygen species balance and responses to oxidative stress in plants. Journal of Experimental Botany, 57, 449-459. https://doi.org/10.1093/jxb/erj027

Devi, R., Munjral, N., Gupta., Anil, K., \& Kaur, N. (2007). Cadmium induced changes in carbohydrate status and enzymes of carbohydrate metabolism, glycolysis and pentose phosphate pathway in pea. Environmental and Experimental Botany, 61,167-174. https://doi.org/10.1016/j.envexpbot.2007.05.006.

Dinkova-Kostova, A. T. (2013). Chemoprotection against cancer by isothio-cyanates: a focus on the animal models and the protective mechanisms. Topics in Current Chemistry, 329, 179-201. https://doi.org/10.1007/128_2012_337

Dubey, R. S., \& Singh, A. K. (1999). Salinity induces accumulation of soluble sugars and alter the activity of sugar metabolizing enzymes in rice plants.Biologia Plantarum, 42, 233-239. https://doi.org/10.1023/A:1002160618700.

Dubois, M., Gilles, K. A., Hamilton, J. K., Rebers, P. A., \& Smith, F. (1956). Colorimetric method for determination of sugars and related substances. Analytical Chemistry, 28(3), 350-356. https://doi.org/10.1021/ac60111a017.

Dumont, E., Vanhaecke, F., \& Cornelis, R. (2006). Selenium speciation from food source to metabolites: a critical review. Analytical and Bioanalytical Chemistry, 385(7), 1304-1323.

El Kassis, E., Cathala, E., Rouached, H., Fourcroy, P., Berthomieu, P., Terry, N., et al. (2007). Characterization of a selenate-resistant Arabidopsis mutant. Root growth as a potential target for selenate toxicity. Plant Physiology, 143, 1231-1241. https://doi.org/10.1104/pp.106.091462

Fiske, C. H., \& Subbarow, Y. (1925). The colorimetric determination of phosphorus. Journal of Biological Chemistry, 66, 375-400.

Gigolashvili, T., \& Kopriva, S. (2014). Transporters in plant sulphur metabolism. Frontiers in Plant Science, 5, 422. https://doi.org/10.3389/fpls.2014.00442

Hartikainen, H., Xue, T., \& Piironen, V. (2000). Selenium as an antioxidant and prooxidant in ryegrass. Plant and Soil, 225,193-200. https://doi.org/10.1023/A:1026512921026

Hatfield, D. L., Tsuji, P. A., Carlson, B. A., \& Gladyshev, V. N. (2014). Selenium and selenocysteine: roles in cancer, health, and development. Trends in Biochemical Sciences, 39, 112-120. https://doi.org/10.1016/j.tibs.2013.12.007

Hubbard, N. L., Huber, S. C., \& Pharr, D. M. (1989) Sucrose Phosphate Synthase and Acid Invertase as Determinant of Sucrose Concentration in Developing Muskmelon (Cucumis melo L.) Fruits. Plant Physiology, 91, 1527-1534. http://dx.doi.org/10.1104/pp.91.4.1527

Huber, S. C., \& Huber, J. L. (1996). Role and regulation of sucrose phosphate synthase in higher plants. Annual Review of Plant Physiology and Plant Molecular Biology, 47, 431-444. http://dx.doi.org/10.1146/annurev.arplant.47.1.431

Khattab, H. (2004). Metabolic and oxidative responses associated with exposure of Eruca sativa (rocket) plants to different levels of selenium. International Journal of Agriculture Biology, 6, 1101-1106.

Kopsell, D. A., Randle, W. M., \& Mills, H. A. (2000). Nutrient accumulation in leaf tissue of rapid-cycling Brassica oleracea responds to increasing sodium selenate concentrations. Journal of Plant Nutrition, 23, 927-935.

Liu, Y., Li, F., Yin, X. B., \& Lin, Z. Q. (2011). Plant-based biofortification from phytoremediation to Se-enriched agriculture products in Green Chemistry for Environmental Sustainability, eds S. K. Sharma and A. Mudhoo (Boca Raton, FL: CRC Press), 341-356.

Lowry, O. H., Rosbrough, N. J., Farr, A. L., \& Randall, R. J. (1951). Protein Measurement with the Folin Phenol Reagent. Journal of Biological Chemistry, 193, 265-275

Marschner, H. (1995). Mineral Nutrition of Higher Plants, Academic Press, ISBN 0-12-473542-8, New York,U.S.A.

Mayer, J. E., Pfeiffer, W. H., \& Beyer, P. (2008). Biofortified crops to alleviate micronutrient malnutrition. Current Opinion in Plant Biology, 11, 166-170. 
McCready, R. M., Guggolz, J., Silviera, V., \& Owens, H. S. (1950). Determination of starch and amylase in vegetables. Analytical Chemistry, 22, 1156-1158. https://doi.org/10.1021/ac60045a016.

Miller, G. L. (1972). Use of dinitrosalicylic acid reagent for determination of reducing sugars. Analytical Chemistry, 31, 426-428. https://doi.org/10.1021/ac60147a030.

Miron, D., \& Schaffer, A. A. (1991). Sucrose Phosphate Synthase, Sucrose Synthase and Invertase Activities in De-veloping Fruit of Lycopersicon esculentum mill. and the Sucrose Accumulating Lycopersicon hirsutum humb. and Bompl. Plant Physiology, 95, 623-627. http://dx.doi.org/10.1104/pp.95.2.623

Mishra, P., \& Dubey, R. S. (2008). Effect of aluminum on metabolism of starch and sugars in growing rice seedlings. Acta Physiologia Plantarum, 30, 265-275

Missana, T., Alonso, U., \& García-Gutiérrez, M. (2009).Experimental study and modeling of selenite sorption ontoillite and smectite clays. Journal of Colloid Interface Science, 334, 132-138. https://doi.org/10.1016/j.jcis.2009.02.059

Mroczek-Zdyrska M., \& Wójcik, M. (2012). The influence of selenium on root growth and oxidative stress induced by lead in Vicia faba L. minor plants. Biological Trace Element Research, 147, 320-328. https://doi.org/10.1007/s12011-011-9292-6

Nelson, N. (1944). A photometric adaptation of the Somogyi method for the determination of glucose.Journal of Biological Chemistry, 153, 375-380.

Pennanen, A., Xue, T., \& Hartikainen, H. (2002).Protective role of selenium in plant subjected to severe UV irradiation stress. Journal of Applied Botany, 76, 66-76.

Poblaciones, M. J., Rodrigo, S., Santamaría, O., Chen, Y., \& McGrath, S. P. (2014). Agronomic selenium biofortification in Triticum durum under Mediterranean conditions: from grain to cooked pasta. Food Chemistry, 146,378-384. https://doi.org/10.1016/j.foodchem.2013.09.070

Quick, P., Sieg, G., Neuhaus, H. E., Feil, R., \& Stitt, M. (1989). Short term water stress lead to stimulation of sucrose synthyesis by activating sucrose phosphate synthase. Planta, 177, 535-546. https://doi.org/10.1007/BF00392622.

Rahoui, S., Chaoui, A., \& Ferjani, E. E. (2008). Differential sensitivity to cadmium in germinating seeds of three cultivars of faba bean (Vicia faba L.) Acta Physiologia Plantarum, 30, 451-456. https://doi.org/10.1007/s11738-008-0142-x.

Rosa, M., Prado, C., Podazza, G., Interdonato, R., González, J. A., Hilal, M., \& Prado, F. E. (2009). Soluble sugars - metabolism, sensing and abiotic stress: a complex network in the life of plants. Plant Signaling Behaviour, 4, 388-393. https://doi.org/10.4161/psb.4.5.8294.

Salisbury, F. B., \& Ross, C. W. (1991). Plant Physiology. 4th Edition, CBS Publishers and Distributors, New Delhi.

Schiavon, M., Pittarello, M., Pilon-Smits, E. A. H., Wirtz, M., Hell, R., \& Malagoli, M. (2012). Selenate and molybdate alter sulfate transport and assimilation in Brassica juncea L. Czern.: implications for phytoremediation. Environmental and Experimental Botany, 75, 41-51. https://doi.org/10.1016/j.envexpbot.2011.08.016

Somogyi, M. (1945). A new reagent for the determination of sugar.Journal of Biological Chemistry, 160, 61-68.

Sors, T. G., Ellis, D. R., \& Salt, D. E. (2005). Selenium uptake, translocation, assimilation metabolic fate in plants. Photosynthesis Research, 86, 373-389.

Sun, H. W., Ha, J., Liang, S. X., \& Kang, W. J. (2010). Protective role of selenium on garlic growth under cadmium stress. Communications in Soil Science and Plant Analysis, 41, 1195-1204. https://doi.org/10.1080/00103621003721395

Vassey, T. L., Quick, W. P., Sharkley, T. D., \& Stitt, M. (1991). Water stress, $\mathrm{CO}_{2}$ and light effects on sucrose phosphate synthase activity in Phaseolus vulgaris. Physiologia Plantarum, 81, 37-44. https://doi.org/10.1111/j.1399-3054.1991.tb01709.x

Verma, S., \& Dubey, R. S. (2001). Effect of cadmium on soluble sugars and enzymes of their metabolism in rice. Biol Plant, 44, 117-123. https://doi.org/10.1023/A:1017938809311.

White, P. J., Bowen, H. C., Parmaguru, P., Fritz, M., Spracklen, W. P., Spiby, R. E., et al. (2004). Interactions between selenium and sulphur nutrition in Arabidopsis thaliana. Journal of Experimental Botany, 55, 
1927-1937. https://doi.org/10.1093/jxb/erh192

Winkel, L. H., Vriens, B., Jones, G. D., Schneider, L. S., Pilon-Smits, E., \& Bañuelos, G. S. (2015). Selenium cycling across soil-plant-atmosphere interfaces: a critical review. Nutrition, 7, 4199-4239. https://doi.org/10.3390/nu7064199

Wu, Z., Bañuelos, G. S., Lin, Z. Q., Liu, Y., Yuan, L., Yin, X, et al. (2015). Biofortification and phytoremediation of selenium in China. Frontiers in Plant Science, 6, 136. https://doi.org/10.3389/fpls.2015.00136.

Yang, J., Zhang, J., Wang, Z., \& Zhu, Q. (2001). Activities of starch hydrolytic enzymes and sucrose phosphate synthase in the stem of rice subjected to water stress during grain filling. Journal of Experimental Botany, 52, 2169-2179.

Yin, X. B., \& Yuan, L. X. (eds.). (2012). "Phytoremediation and biofortification," in Two Sides of One Coin, (Berlin: Springer), 1-31. https://doi.org/10.1007/978-94-007-1439-7.

Zeeman, S. C., Smith, S. M., \& Smith, A. M. (2004). The breakdown of starch in leaves. New Phytologist, 163, 247-261

Zheng, Yi, Anderson, S., Zhang, Y., \& Michael Garavito, R. (2011).The Structure of Sucrose Synthase-1 from Arabidopsis thaliana and Its Functional Implications. Journal of Biological Chemistry, 286, 36108-36118.

Zhou, R., Silcher, R. C., \& Quebedeau, B. (2002). Apple leaf sucrose phosphate synthase is inhibited by sorbitol-6-phosphate. Functional Plant Biology, 29, 569-574. https://doi.org/10.1071/PP01123.

\section{Copyrights}

Copyright for this article is retained by the author(s), with first publication rights granted to the journal.

This is an open-access article distributed under the terms and conditions of the Creative Commons Attribution license (http://creativecommons.org/licenses/by/4.0/). 